\title{
Pancreatic duodenal homeobox-1 and islet neogenesis-associated protein: a possible combined marker of activateable pancreatic cell precursors
}

\author{
J J Gagliardino, H Del Zotto, L Massa, L E Flores and M I Borelli \\ CENEXA - Centre of Experimental and Applied Endocrinology (UNLP-CONICET, PAHO/WHO Collaborating Centre), National University of La Plata \\ School of Medicine, La Plata, Argentina \\ (Requests for offprints should be addressed to J J Gagliardino, CENEXA (UNLP-CONICET), Facultad de Ciencias Médicas, UNLP, Calles 60 y 120 , \\ 1900 La Plata, Argentina; Email:gagliardino@infovia.com.ar)
}

\begin{abstract}
The aim of this work was to study the possible relationship between pancreatic duodenal homeobox-1 (Pdx-1) and islet neogenesis-associated protein (INGAP) during induced islet neogenesis. Pregnant hamsters were fed with (S) and without (C) sucrose, and glycemia, insulin secretion in vitro, and pancreas immunomorphometric parameters were measured in their 7-day-old offspring. S offspring had significantly lower glycemic levels than C animals. Insulin release in response to increasing glucose concentrations in the incubation medium $(2-16 \mathrm{mM}$ glucose) did not increase in pancreata from either $\mathrm{C}$ or $\mathrm{S}$ offspring. However, pancreata from $\mathrm{S}$ offspring released more insulin than those from $\mathrm{C}$ animals. In $\mathrm{S}$ offspring, $\beta$-cell mass, $\beta$-cell replication rate and islet neogenesis increased significantly, with a simultaneous decrease in
\end{abstract}

$\beta$-cell apoptotic rate. INGAP- and Pdx-1-positive cell mass also increased in the islets and among acinar and duct cells. We found two subpopulations of $\mathrm{Pdx}-1$ cells: INGAP-positive and INGAP-negative. Pdx-1/INGAPpositive cells did not stain with insulin, glucagon, somatostatin, pancreatic polypeptide, or neurogenin 3 antibodies. The increment of Pdx-1/INGAP-positive cells represented the major contribution to the $\mathrm{Pdx}-1$ cell mass increase. Such increments varied among pancreas subsectors: ductal >insular>extrainsular. Our results suggested that INGAP participates in the regulation of islet neogenesis, and Pdx-1/INGAP-positive cells represent a new stem cell subpopulation at an early stage of development, highly activateable in neogenesis.

Journal of Endocrinology (2003) 177, 249-259

\section{Introduction}

The mass of pancreatic $\beta$-cells is controlled by two opposite processes: while $\beta$-cell mass expansion depends on $\beta$-cell replication and islet neogenesis (Bonner-Weir 2000), $\beta$-cell apoptosis (Shafrir et al. 1999) leads to the opposite effect.

During embryonic gestation, differentiation into glucagon-, somatostatin-, pancreatic polypeptide (PP)-, and insulin-expressing cells is controlled by the expression of transcription factors such as pancreatic duodenal homeobox-1 (Pdx-1), neurogenin 3 (Ngn-3), NK homobox 6.1 (Nkx 6-1), and others (Edlund 1998, Gradwohl et al. 2000, Jensen et al. 2000, McKinnon \& Docherty 2001). At late fetal gestation and early neonatal life most new $\beta$-cells are formed by the process of neogenesis (Bouwens et al. 1994, Kaung 1994). In adult life, $\beta$-cells are highly differentiated, with a low proliferative capacity that decreases with age (Swenne 1983, Bouwens \& Kloppel 1996, Montanya et al. 2000), and neogenesis is difficult to detect (Wang et al. 1995). However, neo- genesis can be observed in animal models where pancreas regeneration has been induced by a variety of procedures such as alloxan and streptozotocin injection (Fernandes et al. 1997), partial pancreatectomy (Sharma et al. 1999), duct ligation (Wang et al. 1995), or cellophane wrapping of the pancreas head (Rosenberg et al. 1983). In most of these conditions there is an increased proliferation of isolated duct cells concomitant with the expression of $\mathrm{Pdx}-1$, also known as IDX-1, IPF-1, STF-1 and GSF (Karlsson et al. 1987, German et al. 1995, McKinnon \& Docherty 2001). However, little is known about the source of these putative ductal stem cells and their regulation.

We have previously shown that sucrose administration to normal young hamsters induced an increase in $\beta$-cell mass, ascribed to a simultaneous increase in $\beta$-cell replication rate and islet neogenesis (Del Zotto et al. 1999, 2000). These changes were more marked in the offspring of hamsters fed with sucrose during pregnancy (Gagliardino et al. 2000). In both circumstances, the increase in $\beta$-cell mass was accompanied by a significant increase in islet neogenesis-associated protein 
(INGAP)-positive cell mass (Del Zotto et al. 2000). Thus, we have hypothesized that INGAP is involved in sucroseinduced islet cell growth and differentiation.

In an attempt to see whether Pdx-1 and INGAP could be related during the active process of islet neogenesis, we have studied the changes occurring in insulin secretion, $\beta$-cell-, Pdx-1-, and INGAP-positive cell mass, and in $\beta$-cell apoptotic rate, in offspring from normal hamsters receiving $10 \%$ sucrose in the drinking water during pregnancy.

\section{Materials and Methods}

\section{Animals}

Pregnant Syrian hamsters weighing around $60 \mathrm{~g}$ (8 weeks old) were housed in a temperature-controlled room $\left(23{ }^{\circ} \mathrm{C}\right)$ with a fixed $12 \mathrm{~h}$ light: $12 \mathrm{~h}$ darkness cycle (lights on 0600-1800 h). At day 1 of pregnancy (defined as the morning of the discovery of a vaginal plug), they were randomly divided into two groups: the control group (C) had free access to a standard commercial diet and tap water, whereas the treated group $(S)$ received the same diet plus $10 \%$ sucrose in the drinking water. After delivery (lactating period), both groups of animals were maintained on their respective regimens, and their offspring were killed by decapitation 7 days after birth. Water intake was measured daily in both groups, while the body weight of each offspring was recorded at the time of death.

\section{Blood glucose}

Serum glucose levels were measured in every offspring at the time of death (around $0900 \mathrm{~h}$ ) using the Medisense glucometer (Abbott Laboratories Company, Bedford, MA, USA).

\section{Insulin secretion studies}

Due to the small amount of tissue available in 7-day-old animals, we incubated minced pancreata rather than isolated islets (Massa et al. 1997). Briefly, two small pieces of minced pancreas were dropped into a plastic tube $(0.7 \mathrm{~cm}$ diameter) with a permeable bottom (Whatman filter-paper disk stuck to the walls of the tube); this tube was inserted into another $(1.0 \mathrm{~cm}$ internal diameter $)$ containing Krebs-Ringer bicarbonate buffer, $400 \mathrm{U} / \mathrm{ml}$ aprotinin, and different concentrations of glucose $(2,8$, and $16 \mathrm{mM})$. The pieces of pancreas were then incubated for $60 \mathrm{~min}$ at $37^{\circ} \mathrm{C}$; at the end of this period, the inner tube containing the pieces of pancreas was removed, allowed to settle overnight in an oven at $37^{\circ} \mathrm{C}$, and then weighed. The incubation medium was collected for insulin determination by radioimmunoassay (Herbert et al. 1965). For this procedure, we used an antibody against rat insulin and rat insulin standard (Linco Research Inc., St Charles, MI, USA), and highly purified porcine insulin labeled with ${ }^{125} \mathrm{I}$ (Linde et al. 1980). Parallel tracer displacement curves were obtained using either the rat insulin standard, or partially purified insulin extracted from hamster pancreata.

\section{Immunohistochemical studies}

The whole pancreas was removed and its wet weight was recorded. The pancreas was then fixed in Bouin's fluid and embedded in paraffin. Serial sections of fixed pancreas $(5 \mu \mathrm{m})$ were obtained from three different levels of the blocks with a rotatory microtome, and mounted on silanized slides (3-amino-propyltriethoxy-silane; Sigma Co., St Louis, MO, USA) (Hsu et al. 1981). Sections were deparaffinized, incubated for $30 \mathrm{~min}$ in 3\% hydrogen peroxide in methanol to block endogenous peroxidase activity, and rehydrated in a descending ethanol series, followed by an incubation in $2.5 \%$ porcine serum to reduce non-specific binding. The slides were then incubated for $24 \mathrm{~h}$ at $4{ }^{\circ} \mathrm{C}$ in a humidified chamber with different appropriately diluted primary antibodies. For the final staining of all these cell types, we used the streptavidin-biotin complex (1:40 and 1:20 respectively; Sigma), or alkaline phosphatase (1:40; Sigma). The incubation period for this step-procedure was 30 min with the secondary biotinylated antibodies or alkaline phosphatase.

Figure 1 (opposite) (a) Paraffin section of a C pancreas treated with antibodies against INGAP and Pdx-1. Pdx-1-positive cells can be seen in islet $\beta$-cells. Arrows show INGAP (blue cytoplasm)/Pdx-1-positive (red nucleus) cells in islet non- $\beta$-cells $(\times 200)$. (b) The same islet section, stained with glucagon antibody and Texas red. INGAP/Pdx-1-positive cells (arrows) did not react with the glucagon antibody $(\times 200)$. (c) The same islet section as in (a) and (b), stained with insulin antibody and peroxidase-carbazole. In this case, the Pdx-1 antibody was not used to avoid stain overlapping. INGAP/Pdx-1-positive cells (arrows) did not react with the insulin antibody $(\times 200$ ). (d) Negative control of combined immunostaining by omission of the first antibody (PCNA and INGAP). (e) C offspring pancreas section treated with INGAP (blue) and PCNA (red) antibodies. The arrow shows a cell stained positively with both antibodies at the islet periphery ( $\times$ 200). (f) S offspring pancreas section treated with INGAP (blue) and PCNA (red) antibodies. The arrows show two cells stained positively with both antibodies at the islet periphery $(\times 200)$. (g) Negative control of immunostaining by omission of the first antibody (CK). (h) C offspring pancreas section treated with the CK 19 (clone 4.62; Sigma) antibody (peroxidase-carbazole) counterstained with hematoxylin. Scanty CK-positive cells are seen at the islet periphery $(\times 100)$. (i) S offspring pancreas section treated with the CK 19 (clone 4.62; Sigma) antibody (peroxidase-carbazole) counterstained with hematoxylin. Numerous CK-positive cells are seen at the islet periphery $(\times 100)$. (j) Negative control of combined immunostaining by omission of the first antibody (INGAP and Pdx-1). (k) C offspring pancreas section treated with antibodies against INGAP and Pdx-1. The arrow shows INGAP (blue cytoplasm)/Pdx-1-positive (red nucleus) cells in the periphery of the islet $(\times 400)$. (I) $\mathrm{S}$ offspring pancreas section treated with antibodies against INGAP and Pdx- 1 . The arrows show INGAP (blue cytoplasm)/Pdx-1-positive (red nucleus) cells in the islet $(\times 400)$. 
Cell replication rates

We performed sequential double staining for proliferating cell nuclear antigen (PCNA; 1:4000; Sigma) and $\beta$-cells (1:20 000; our own guinea pig-insulin antibody), PCNA and non- $\beta$-cells with a mixture of three different rabbit antibodies against somatostatin (1:6000; DAKO, Glostrup, Denmark), glucagon (1:400; Peninsula Laboratories,
Belmont, CA, USA), and PP (1:10 000; Novo Nordisk A/S, Bagsvaerd, Denmark), and PCNA and INGAP cells with rabbit INGAP antibody (IgG1246; 1:600; Eli Lilly Co., Indianapolis, IN, USA). First, we performed PCNA staining as described above using carbazole as chromogen; the same section was then immunostained for $\beta-$, non- $\beta$ and INGAP cell identification as already described, except
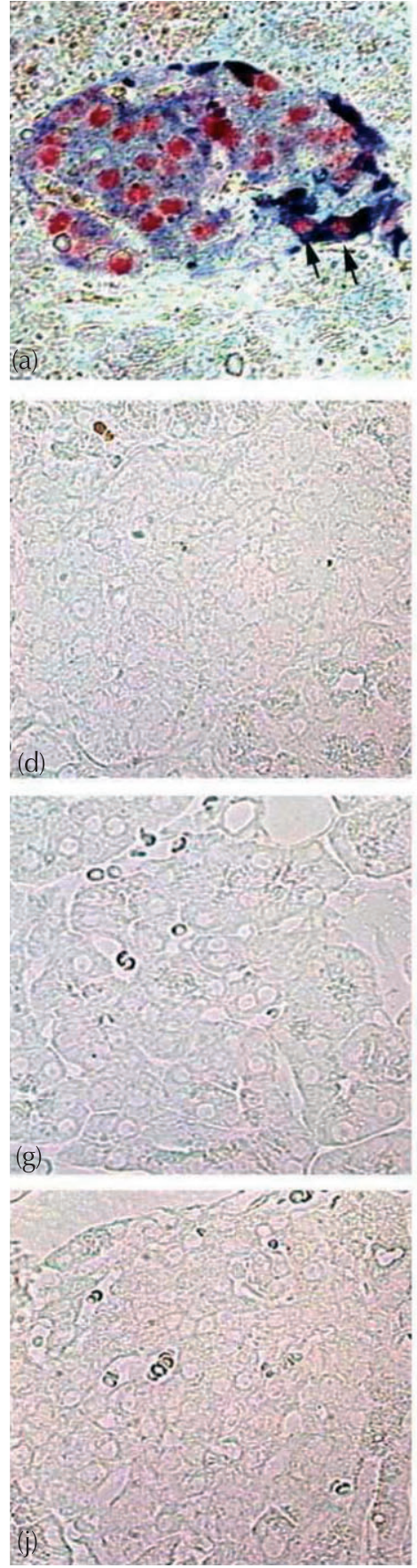
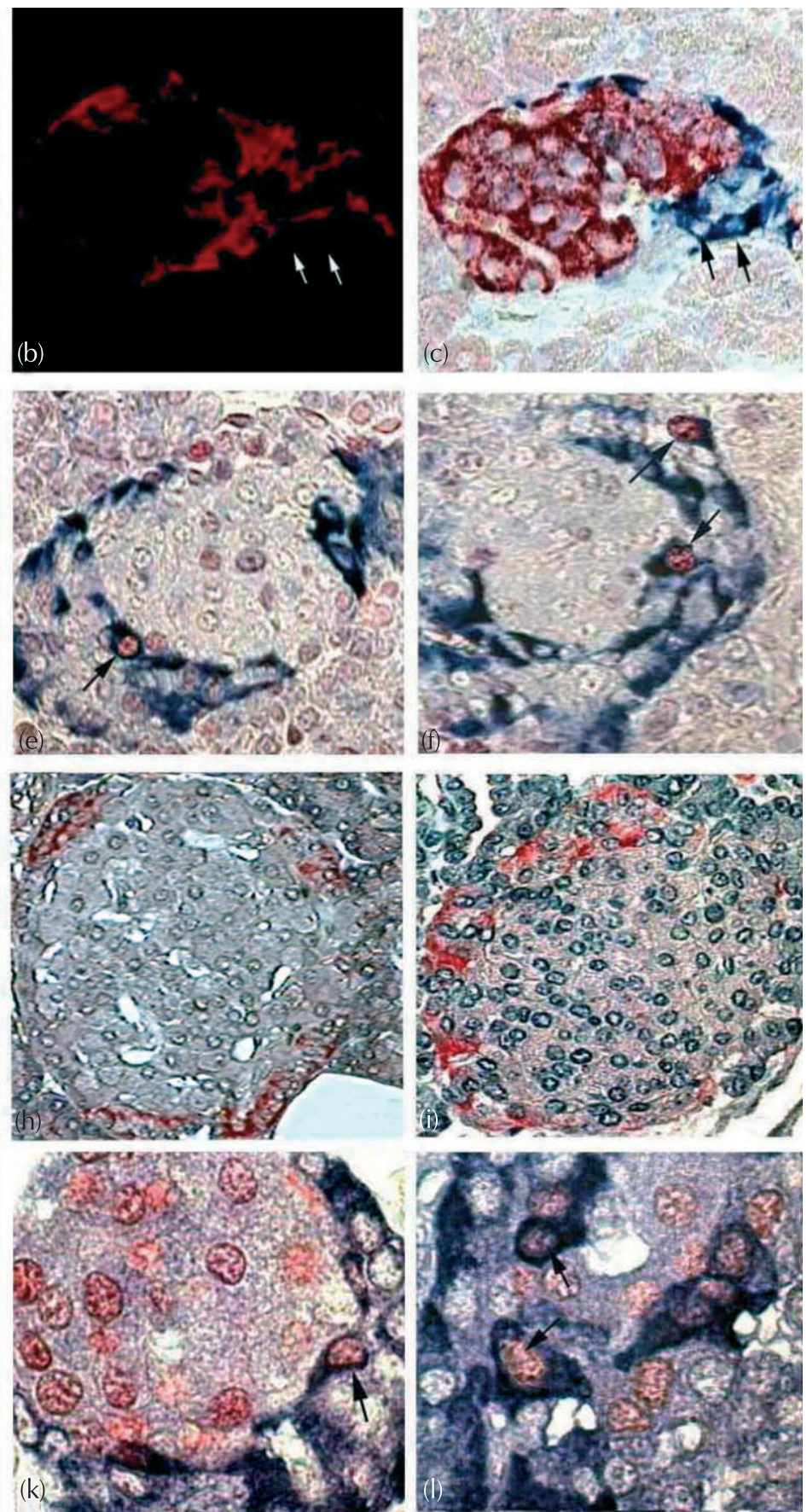
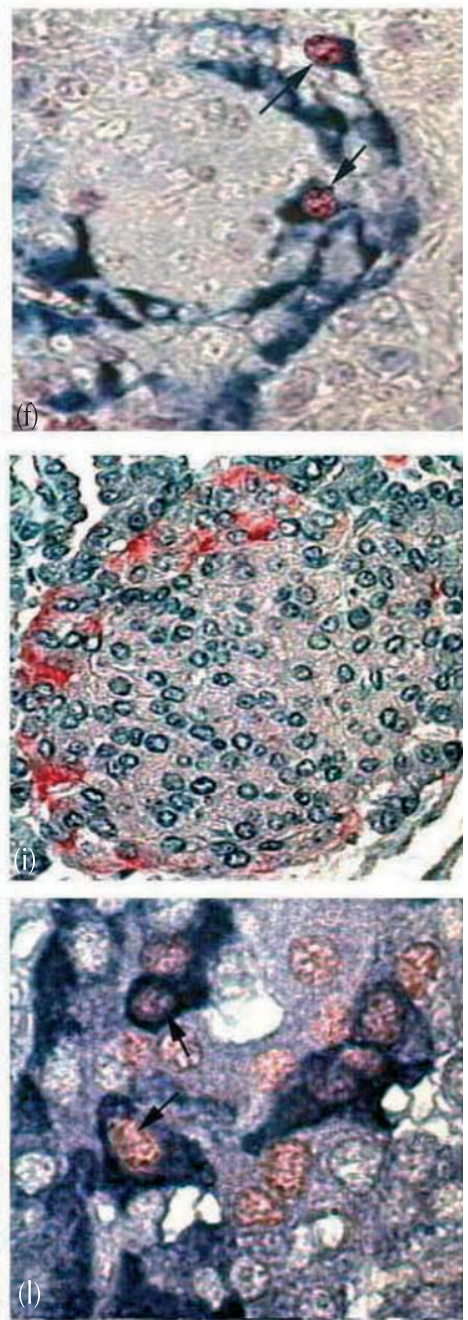
that alkaline phosphatase and fast blue (Sigma) were used as chromogens. Alkaline phosphatase conjugate was applied to each section for $30 \mathrm{~min}$ at room temperature; the sections were then washed, and alkaline phosphatase substrate was applied for another $30 \mathrm{~min}$. Sections were further washed and mounted in aqueous medium (DAKO). Within a given cell type, the replication rate was quantified and expressed as the percentage of PCNAlabeled cells among the total $\beta-$, non- $\beta$-, and INGAP cells counted (no less than 3000 each). On the other hand, at ductal level immunostained cells (PCNA and INGAP) were expressed as the number of positive cells per area $\left(\mathrm{mm}^{2}\right)$. Immunocytochemical stainings have been validated in previous studies (Del Zotto et al. 1999, 2000). Further, for every immunostaining, simple controls were done by omitting the primary antiserum.

\section{Apoptotic rate}

To identify apoptotic bodies, the propidium iodide technique was used (Scaglia et al. 1997). For this purpose, deparaffinized and rehydrated sections were washed in phosphate-buffered saline before incubation for $30 \mathrm{~min}$ in a dark humidified chamber with a solution of propidium iodide $(4 \mu \mathrm{g} / \mathrm{ml}$; Sigma $)$ and ribonuclease A $(100 \mu \mathrm{g} / \mathrm{ml}$; Sigma). A Zeiss Axiolab epifluorescence microscope equipped with an $\mathrm{HBO} 50$ mercury lamp, together with two different filters, was used for visualization of autofluorescent labeling (propidium iodide) to detect apoptotic bodies. Glucagon immunofluorescence staining (fluorescein isothiocyanate; FITC) was used to reveal peripheral islet cells.

For quantitative evaluation, positively labeled apoptotic endocrine cells were counted under a $\times 40$ objective lens in sections obtained from different levels of the blocks. The number of apoptotic cells was expressed as the percentage of the total number of $\beta$ and non- $\beta$-cells counted.

\section{Cytokeratin (CK) immunostaining}

For antigen retrieval, deparaffinized sections were pretreated with $250 \mathrm{ml}$ antigen-retrieval solution (Vector Laboratories, Burlingame, CA, USA) for $10 \mathrm{~min}$ in a $500 \mathrm{~W}$ microwave oven (Madsen et al. 1997). To reveal the presence of CK-positive cells, we used a panspecific cocktail of antibodies against human CK clone AE1-AE3 (DAKO) and CK 19 (Sigma clone 4·62).

\section{Detection of Pdx-1- and INGAP-positive cells}

Sequential double staining for Pdx-1 and INGAP detection in pancreatic cells was as follows. We first stained Pdx-1 cells with the Pdx-1 antibody (1:1200; kindly provided by Dr C Wright, Department of Cell Biology,
Vanderbilt University, Nashville, TN, USA), and revealed them as described above using carbazole as chromogen; the same section was then immunostained with the INGAP antibody (1:250), except that alkaline phosphatase and fast blue (Sigma) were used as chromogens. Later, the percentage of cells expressing separately or co-expressing these two factors was quantified within each subsector of the pancreas, i.e. islet, extrainsular, and duct cells (no less than 1000 each). In addition, glucagon (fluorescein) and somatostatin (Texas red) were used to reveal co-expression of these hormones with Pdx-1 and INGAP.

\section{Detection of Ngn-3-positive cells}

Deparaffinized sections pretreated for antigen retrieval (see above) were incubated for $24 \mathrm{~h}$ at $4{ }^{\circ} \mathrm{C}$ in a humidified chamber with anti-rabbit Ngn-3 antibody (1:2000, provided by Dr M German, University of California, San Francisco, CA, USA). The final staining was accomplished with the streptavidin-biotin complex (1:40 and 1:20 respectively; Sigma). The incubation period for this stepprocedure was $30 \mathrm{~min}$ with the secondary biotinylated antibodies, and they were revealed using carbazole as chromogen. Sections of normal mouse (gestational age, $15 \cdot 5$ days; E15.5) were used as positive controls.

\section{Morphometrical analysis}

The morphometrical analysis was performed by videomicroscopy using a Jenamed 2 Carl Zeiss light microscope and an RGB CCD Sony camera in combination with OPTIMAS software (Bioscan Incorporated, Edmons, WA, USA). We measured the following parameters: total pancreas area excluding connective tissue; endocrine pancreas area; exocrine pancreas area; $\beta$ - and non- $\beta$-cell area; number of $\beta$ - and non- $\beta$-cells; the areas and number of cells with and without Pdx-1/INGAP co-expression; the number of islets per unit area; and islet volume. We also estimated the volume density of $\beta$ - and non- $\beta$-cells, $\mathrm{Pdx}-1 / \mathrm{INGAP}$ and Pdx-1 cells, as well as the size of $\beta$ and non- $\beta$-cells. To estimate islet $\beta$-cell, non- $\beta$-cell, INGAP/Pdx-1, extrainsular, ductal, and CK mass, we multiplied the respective volume densities by the total weight of the pancreas (Bonner-Weir \& Smith 1994). We also estimated the relationship between the islets and duct cells, expressed as a percentage of the total number of islets in contact with ducts (Bertelli et al. 2001).

\section{Statistical analysis}

Quantitative data are expressed as means \pm S.E.M. The statistical significance was determined by Student's $t$-test. A $P$ value of $<0.05$ was considered statistically significant. 


\section{Results}

Body weight, daily food ingestion and water intake of pregnant hamsters

Comparable body weights were recorded in $\mathrm{C}$ and $\mathrm{S}$ pregnant hamsters at the end of the experiments $(78 \cdot 3 \pm 7 \cdot 2$ vs $76 \cdot 1 \pm 8 \cdot 6 \mathrm{~g})$. S animals drank a significantly larger volume of water than $\mathrm{C}$ animals $(16 \cdot 0 \pm 0 \cdot 7$ vs $10 \pm 0 \cdot 1 \mathrm{ml} /$ day; $P<0 \cdot 005)$. Equivalent amounts of food (and caloric intake) were consumed daily by $\mathrm{C}$ and $S$ hamsters $(17 \pm 2$ vs $14 \pm 1 \mathrm{~g}$, and $79 \cdot 0 \pm 0 \cdot 9$ vs $79 \cdot 9 \pm 1$ Cal respectively). Due to the presence of sucrose in the drinking water, the $\mathrm{S}$ group received a qualitatively different daily intake of nutrients as compared with $\mathrm{C}$ animals (carbohydrates:proteins:lipids; 66:26:8 vs 45:43:12 respectively).

\section{Body weight and pancreas weight of the offspring}

Significant differences were recorded in the body weight of $\mathrm{C}$ vs $\mathrm{S}$ offspring $(7 \cdot 3 \pm 0 \cdot 3$ vs $8 \cdot 4 \pm 0 \cdot 2 \mathrm{~g} \quad(n=25)$; $P<0 \cdot 005)$. In contrast, no differences in pancreas weight were recorded between the two groups $(19 \pm 0.9$ vs $20 \cdot 8 \pm 0 \cdot 5 \mathrm{mg}(n=25))$.

\section{Serum glucose levels in the offspring}

Similar fasting serum glucose levels were found in C and $\mathrm{S}$ normal adult hamsters $(128 \pm 7 \mathrm{mg} / \mathrm{dl})$. While values from $\mathrm{C}$ offspring were in the same range as those measured in adult hamsters, they were significantly lower in $\mathrm{S}$ offspring $(128 \pm 3.4$ vs $88.5 \pm 3.8 \mathrm{mg} / \mathrm{dl} \quad(n=16)$ respectively; $P<0 \cdot 001)$.

\section{Insulin released in vitro by pancreas pieces from the offspring}

The release of insulin in pancreata from either $\mathrm{C}$ or $\mathrm{S}$ offspring did not increase in response to increasing glucose concentration in the incubation medium $(2,8$, and $16 \mathrm{mM}$ glucose). However, the pieces of pancreas from $\mathrm{S}$ offspring released more insulin than did those from $\mathrm{C}$ ones $(\mathrm{C}$ vs $\mathrm{S}$, $n=18)$ at any concentration tested: $2 \mathrm{mM}$ glucose: $0 \cdot 8 \pm 0 \cdot 2$ vs $1 \cdot 7 \pm 0 \cdot 4, P<0 \cdot 025 ; 8 \mathrm{mM}$ glucose: $0 \cdot 5 \pm 0 \cdot 2$ vs $1.8 \pm 0.4, \quad P<0.02 ; 16 \mathrm{mM}$ glucose: $0.7 \pm 0.1$ vs $1 \cdot 7 \pm 0 \cdot 4 \mathrm{ng} / \mathrm{mg}$ wet weight $(P<0 \cdot 025)$.

\section{Morphological studies}

In both groups, pancreatic islets of variable shape and size showed $\beta$-cells occupying the central zone, and non- $\beta$ and INGAP-positive cells located at the islet periphery. The exocrine pancreas was composed of characteristic serous acini surrounded by loose connective tissue. The ducts were lined by cubic or cylindrical cells, embedded in dense connective tissue.

A small number of ductal cells reacted positively with the insulin-specific antibody and with the pooled mixture of antisera against non- $\beta$-cell hormones. In the islets, while Pdx-1-positive cells were located in the central zone, INGAP-positive cells were only seen at the islet periphery (Fig. 1a and c).

There were two subpopulations of Pdx-1-positive cells, only one of which co-stained with INGAP. The Pdx-1/ INGAP-positive cells did not exhibit positive staining with anti-insulin, glucagon (Fig. $1 \mathrm{~b}$ and c), somatostatin, or PP antibodies (Fig. 2). Conversely, cells only positive for Pdx-1 stained positively with insulin, while $40 \%$ of INGAP-positive cells co-stained with glucagon antibodies (Del Zotto et al. 2000). Neither of these two subpopulations of $\mathrm{Pdx}-1$-positive cells reacted with the Ngn-3 antibody in either group of animals (Fig. 3). Pancreata from C and S offspring showed Pdx-1/INGAPpositive cells in the islets (Fig. $1 \mathrm{k}$ and 1 ), as well as at extrainsular (Fig. 4b and c) and ductal (Fig. 4e, f, and g) levels.

PCNA antibody labeled nuclei from exocrine-, ductal-, $\beta$-, and INGAP-positive cells in C and S offspring (Fig. 1e and $\mathrm{f}$ ).

CK-positive cells were depicted at the islet periphery (Fig. $1 \mathrm{~h}$ and $\mathrm{i}$ ), being more abundant in $\mathrm{S}$ islets (Fig. 1i: $320 \pm 20$ vs $190 \pm 10 \mu \mathrm{g} ; P<0 \cdot 04)$, and in close proximity to duct cells (Fig. 4i).

\section{Morphometrical studies}

Pancreatic $\beta$-cell mass increase in $\mathrm{S}$ offspring (Table 1) was $114 \%(P<0 \cdot 005)$, with a concomitant $59 \%$ increase in the PCNA index of these cells $(P<0 \cdot 02)$, and a $350 \%$ decrease in $\beta$-cell apoptotic rate $(P<0 \cdot 01)$. Apoptotic $\beta$-cells stained with propidium iodide were not accompanied by any detectable inflammatory reaction. Both exocrine and duct cells with fragmented or condensed nuclei were also observed, but they were not quantified.

There were no marked differences between $\mathrm{C}$ and $\mathrm{S}$ offspring either in non- $\beta$-cell mass $(260 \pm 10$ vs $250 \pm 10 \mu \mathrm{g})$ or in the percentage of PCNA-labeled non- $\beta$-cell nuclei $(1.33 \pm 0.03$ vs $1.3 \pm 0.2 \%)$.

CK-positive cell mass increased significantly in pancreata from S offspring $(320 \pm 20$ vs $190 \pm 10 \mu \mathrm{g}$; $P<0 \cdot 04)$. These animals also showed a significant increase in the number of PCNA-reacting ductal cells ( $\mathrm{S}$ vs $\mathrm{C}$ : $11.9 \pm 0 \cdot 8$ vs $5 \cdot 8 \pm 1 \cdot 6$ cells $\left./ \mathrm{mm}^{2} ; P<0 \cdot 002\right)$. Taking advantage of the fact that ductal cells stained with the CK antibody, we counted the percentage of islets in close contact with these cells, and showed that sucrose treatment increased the percentage of such cells significantly $(88 \cdot 6 \pm 5 \cdot 0$ vs $64 \cdot 0 \pm 7 \cdot 2 ; P<0 \cdot 02)$ (Fig. $4 \mathrm{~h}$ and $\mathrm{i}$ ).

The mass of INGAP-positive cells increased significantly in the islet, the extrainsular, and the ductal pancreas compartments in S offspring (Table 2). The magnitude of such increases was different in each level: ducts, 350\%; islet, 300\%; extrainsular, $86 \%$. The PCNA index of overall INGAP-positive cells also increased by $168 \%(P<0 \cdot 002)$. 

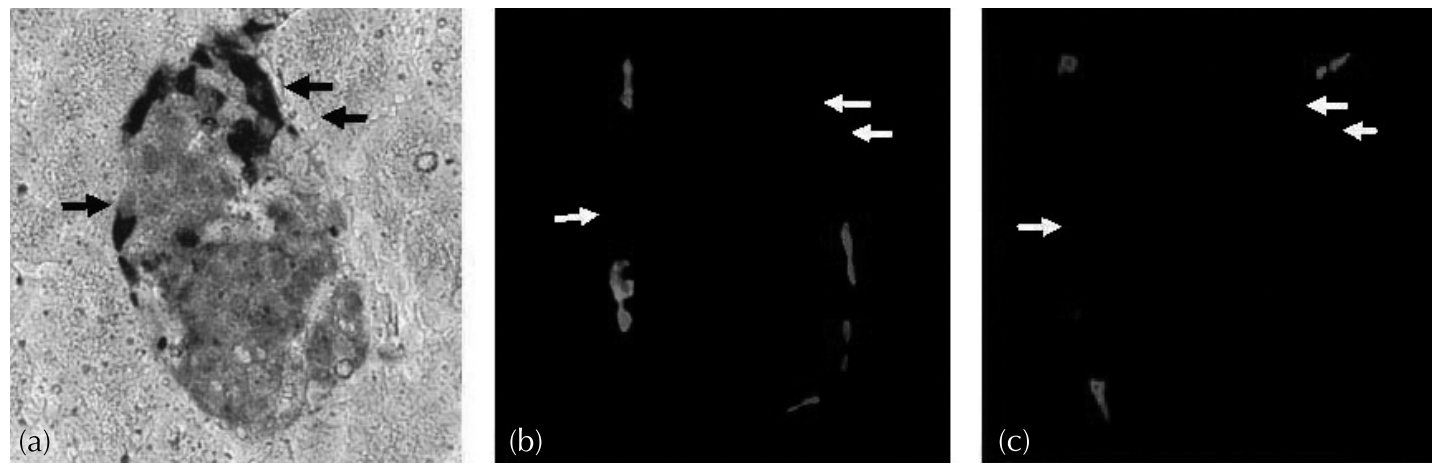

Figure 2 (a) Paraffin section of a $C$ pancreas treated with antibodies against Pdx-1 and INGAP. The islet shows Pdx-1 localization in $\beta$-cells (center), while the INGAP (black cytoplasm)/Pdx-1- (gray nucleus) positivity (arrows) is only seen in cells located in the periphery of the islet $(\times 200)$. (b) The same section as in (a) treated with an antibody against somatostatin, detected by FITC (arrows show no INGAP/Pdx-1 colocalization) ( $\times 200$ ). (c) The same section as in (a) treated with an antibody against PP, detected by Texas red (arrows show no INGAP/Pdx-1 colocalization) $(\times 200)$.
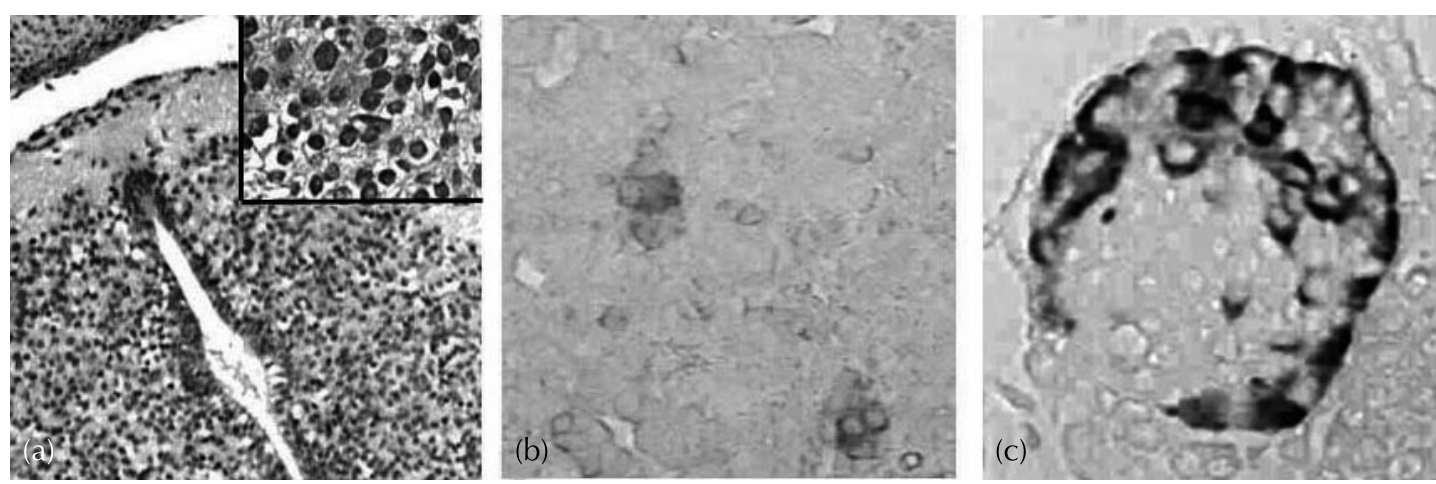

Figure 3 (a) Paraffin section of medulla spinalis from an E15.5 mouse (control staining) treated with Ngn-3 antibody and revealed by carbazole. The black nucleus represents Ngn-3-positive cells $(\times 100)$. Inset: section of the slide at a higher magnification $(\times 400)$. (b) Paraffin section of the pancreas from an E15.5 mouse sequentially treated with Ngn-3 and INGAP antibodies, stained with phosphatase-fast blue (Ngn-3) and peroxidase-carbazole (INGAP). While no Ngn-3positive nuclei are depicted in the pancreas, some INGAP-positive cells can be seen within small islets $(\times 100)$.

(c) Paraffin section of a hamster offspring treated as in (b). No Ngn-3-positive nuclei are seen in the pancreas, while a ring of INGAP-positive cells is seen in the islet $(\times 200)$.

Most of the Pdx-1-positive cells were located at islet level $(98 \%)$, with a smaller proportion at extrainsular $(1 \cdot 8 \%)$ and ductal $(0 \cdot 2 \%)$ level. Sucrose administration induced an overall $111 \%$ increase in the mass of Pdx-1positive cells, from $886 \pm 103 \cdot 2$ to $1872 \pm 205 \mu \mathrm{g}$ $(P<0 \cdot 005$; Table 3$)$, with an uneven increment in each subsector: ductal, 350\% (P<0.001); islet, 112\% $(P<0 \cdot 005)$; extrainsular, 69\% (not significant).

The two subpopulations of $\mathrm{Pdx}-1$-positive cells (Pdx-1/INGAP-positive and Pdx-1/INGAP-negative) participated in a significantly different manner in the sucrose-induced increase of $\mathrm{Pdx}-1$-positive cell mass, particularly when considering their distribution at the three pancreas compartments. Comparing Pdx-1/ INGAP-positive vs Pdx-1/INGAP-negative cells, their mass increased 500 vs $200 \%$ at ductal level, 114 vs $114 \%$ in the islets, and 100 vs $17 \%$ at extrainsular level (Fig. 5). Similar changes were observed when the number of Pdx-1 cells instead of their mass was considered (Table 4). These results suggested that, except for the islets, the sucroseinduced increase of the Pdx-1 cell mass mainly affected the Pdx-1/INGAP-positive cell subpopulation.

\section{Discussion}

Sucrose administration to young normal hamsters for up to 24 weeks did not significantly affect either body weight or glycemic levels (Del Zotto et al. 1999, 2000). Similarly, no significant differences in these two parameters were recorded in the mothers of $\mathrm{C}$ and $\mathrm{S}$ offspring at the time of delivery. Conversely, 7-day-old $\mathrm{S}$ offspring were 

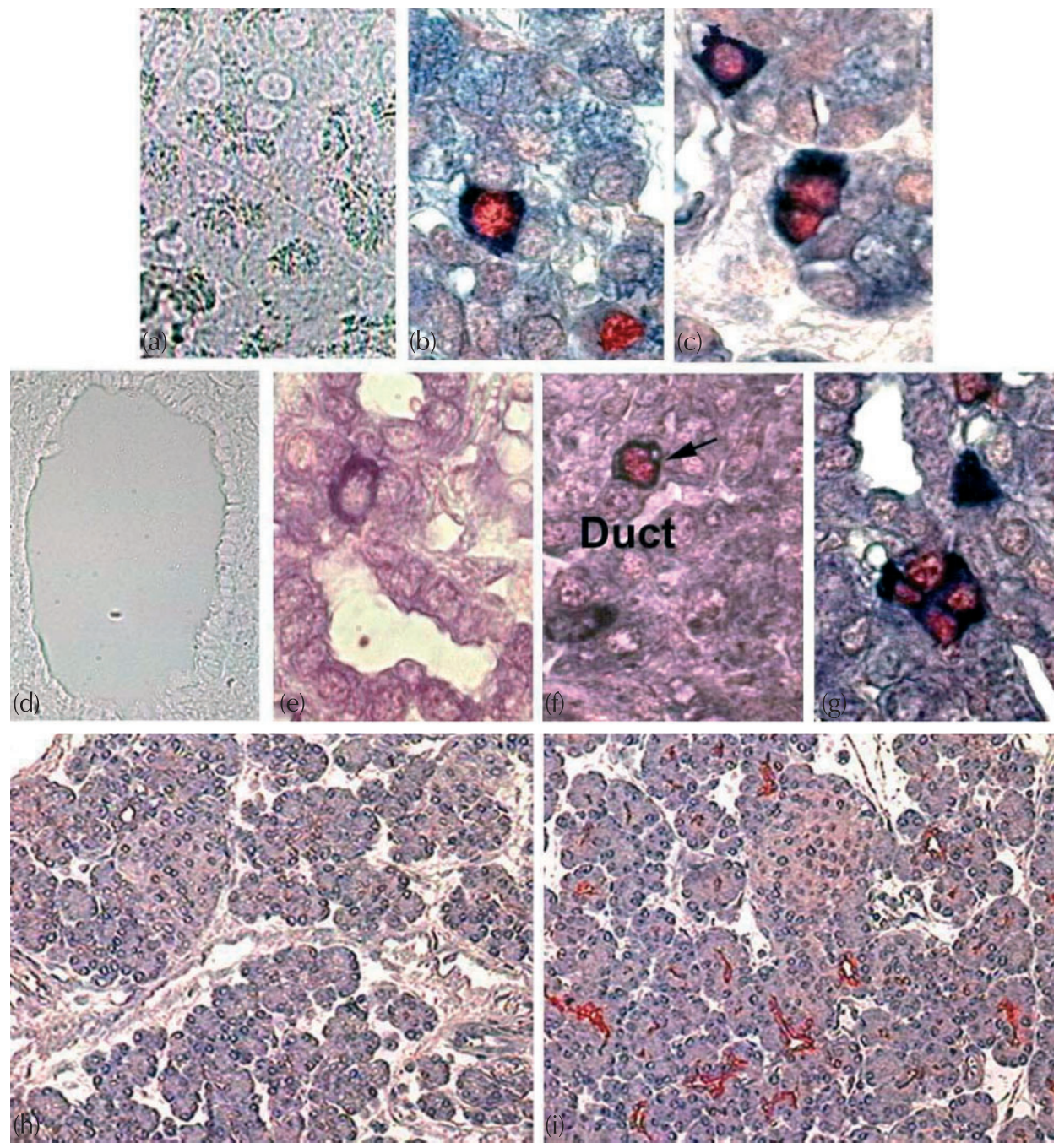

Figure 4 (a) Negative control of combined immunostaining of extrainsular cells by omission of the first antibody (INGAP and Pdx-1). (b) C offspring pancreas section double treated with INGAP (blue) and Pdx-1 (red) antibodies. Note an extrainsular cell reacting positively with INGAP (blue cytoplasm) and Pdx-1 (red nucleus) $(\times 400)$. (c) S offspring pancreas section double treated with INGAP (blue) and Pdx-1 (red) antibodies. Three extrainsular cells reacting positively with INGAP (blue cytoplasm) and Pdx-1 (red nucleus) can be seen $(\times 400)$. (d) Negative control of ductal cells obtained by omission of the first antibody (Pdx-1 and INGAP). (e) C offspring pancreas section double treated with INGAP and Pdx-1 antibodies. A single INGAP-positive ductal cell (blue cytoplasm) can be seen $(\times 400)$. (f) C offspring pancreas section double treated with INGAP (blue) and Pdx-1 (red) antibodies. Note one INGAP-positive (blue cytoplasm) and Pdx-1-positive (red nucleus) ductal cell $(\times 400)$. (g) S offspring pancreas section double treated with INGAP (blue) and Pdx-1 (red) antibodies. Four INGAP-positive (blue cytoplasm) and Pdx-1-positive (red nucleus) ductal cells can be seen $(\times 400)$. (h) C offspring pancreas section stained with the $C K$ antibody (pool against $C K s E_{1}-A E_{3}$ ). No positive $C K$ reaction can be detected either at ductal or islet level $(\times 100)$. (i) $\mathrm{S}$ offspring pancreas section stained with the CK antibody (pool against CKs A-1/A-3). Note CK-positive duct cells in close contact with the islet $(\times 100)$.

significantly heavier and had significantly lower serum glucose levels than $\mathrm{C}$ offspring. The greater release of insulin displayed in vitro by pancreata from $\mathrm{S}$ offspring, together with their inability to differentiate increasing glucose concentrations in the incubation media, could account for the above-mentioned changes. Such inability of $\mathrm{C}$ and $\mathrm{S}$ offspring to recognize different glucose concentrations in the incubation media was not totally unexpected, since in normal hamsters a typical glucose: insulin secretion curve is obtained at 8 weeks, whereas maximal insulin release is only attained at 24 weeks of age (Massa et al. 1997). 
Table 1 Morphometrical changes induced in the $\beta$-cell area of offspring from sucrose-fed hamsters during pregnancy. Each value represents the mean of three animals and three section levels in each group \pm S.E.M.

\begin{tabular}{|c|c|c|c|}
\hline & $\begin{array}{l}\boldsymbol{\beta} \text {-cell mass } \\
(\mu \mathrm{g})\end{array}$ & $\begin{array}{l}\text { PCNA } \boldsymbol{\beta} \text {-cells } \\
(\%)\end{array}$ & $\begin{array}{l}\text { Apoptotic } \\
\text { index (\%) }\end{array}$ \\
\hline \multicolumn{4}{|l|}{ Group } \\
\hline Control & $700 \pm 100$ & $2 \cdot 9 \pm 0 \cdot 3$ & $0 \cdot 9 \pm 0 \cdot 01$ \\
\hline Sucrose & $1500 \pm 200^{\mathrm{a}}$ & $4 \cdot 6 \pm 0 \cdot 1^{b}$ & $0 \cdot 2 \pm 0 \cdot 01^{\mathrm{c}}$ \\
\hline
\end{tabular}

Table 2 Morphometrical changes induced in INGAP-cell mass in the three pancreatic subsectors. Values are the means of three animals and three section levels in each group \pm S.E.M.

\begin{tabular}{|c|c|c|c|c|}
\hline & \multicolumn{3}{|c|}{ INGAP-cell mass $(\mu \mathrm{g})$} & \multirow{2}{*}{$\begin{array}{l}\text { PCNA of } \\
\text { INGAP+ } \\
\text { cells (\%) }\end{array}$} \\
\hline & Insular & Extrainsular & Ductal & \\
\hline \multicolumn{5}{|l|}{ Group } \\
\hline Control & $100 \pm 2$ & $14 \pm 4$ & $2 \pm 0 \cdot 2$ & $2 \cdot 5 \pm 0 \cdot 2$ \\
\hline Sucrose & $400 \pm 2^{a}$ & $26 \pm 2$ & $9 \pm 0 \cdot 1^{\mathrm{a}}$ & $6 \cdot 7 \pm 0 \cdot 9$ \\
\hline
\end{tabular}

${ }^{\mathrm{a}} \mathrm{P}<0 \cdot 000001$.

Table 3 Compartmentalization of Pdx-1-positive cell mass. Each value represents the mean of three animals and three section levels in each group \pm S.E.M.

\begin{tabular}{|c|c|c|c|}
\hline & Control & Sucrose & $\begin{array}{l}\text { Increase } \\
(\%)\end{array}$ \\
\hline Subsector & & & \\
\hline $\begin{array}{l}\text { Insular }(\mu \mathrm{g}) \\
\text { Extrainsular }(\mu \mathrm{g})\end{array}$ & $\begin{array}{c}868 \pm 100(98 \%) \\
16+3(1.8 \%)\end{array}$ & $\begin{array}{c}1836 \pm 200(98 \%)^{a} \\
27+4(1 \cdot 4 \%)\end{array}$ & $\begin{array}{r}112 \\
69\end{array}$ \\
\hline $\begin{array}{l}\text { Extrainsular }(\mu \mathrm{g}) \\
\text { Ductal }(\mu \mathrm{g})\end{array}$ & $\begin{array}{r}16 \pm 3(1 \cdot 8 \%) \\
2 \pm 0(0 \cdot 2 \%)\end{array}$ & $\begin{aligned} 27 & \pm 4(1 \cdot 4 \%) \\
9 & \pm 1(0 \cdot 6 \%)^{b}\end{aligned}$ & $\begin{array}{r}69 \\
350\end{array}$ \\
\hline
\end{tabular}

${ }^{\mathrm{a}} P<0 \cdot 005 ;{ }^{\mathrm{b}} \mathrm{P}<0 \cdot 001$.

Offspring from $\mathrm{S}$ hamsters showed a significant $114 \%$ increase in the mass of $\beta$-cells, conditioned by a simultaneous increase in the replication rate of $\beta$-cells (59\%), a decrease in $\beta$-cell apoptotic rate $(350 \%)$, and increased islet neogenesis. Objective evidence supports the occurrence of the latter process, namely, increased CK-positive cell mass (Bouwens et al. 1994), islet percentage in close contact with the ducts (Bertelli et al. 2001), ductal cell replication rate (Sharma et al. 1999), and Pdx-1-positive cell mass (McKinnon \& Docherty 2001).

The strong concomitant changes observed in INGAP cell mass and replication rate would also indicate that INGAP could be effectively involved in the regulation of such neogenetic processes rather than being simply casually related. The fact that sucrose administration only induced an increase in INGAP cell mass when islet neogenesis occurred (Del Zotto et al. 2000), together with our recent report of its transcription at islet level (Flores et al. 2003) would reinforce this assumption.
Sucrose administration to 8 -week-old hamsters induced a significant increase in glucose-induced insulin secretion, $\beta$-cell mass (Del Zotto et al. 1999), and INGAP-positive cell mass (Del Zotto et al. 2000), but not in $\beta$-cell apoptotic rate or in the replication rate of ductal or islet INGAP-positive cells, as it currently occurred in S offspring. These facts might indicate that sucrose administration at this early stage of pancreatic development affects all the processes involved in pancreas remodeling and insulin secretion.

Although Pdx-1 plays an important role in the development of the pancreas and is expressed in pancreatic duct, endocrine, and acinar cells, its distribution becomes more restricted in the mature pancreas (Stoffers et al. 2000, McKinnon \& Docherty 2001). Using different experimental approaches and detection methodologies, however, other authors have also found a concomitant increase of islet neogenesis and Pdx-1 in adult life: Sharma et al. (1999) measured a fivefold increase of $\mathrm{Pdx}-1$ protein levels (Western blot analysis) in rat islets 3 days after partial pancreatectomy. At that period, most epithelium cells of the common pancreatic duct stained positively for Pdx-1, this effect being preceded by an increase in the replication rate of duct cells. An increase in islet size together with a three- to fourfold increase in the expression of $\mathrm{Pdx}-1$ of total pancreatic protein (Western blot analysis) was also reported during a 2-week glucagon-like peptide-1 administration to control non-diabetic and $\mathrm{db} / \mathrm{db}$ mice (Stoffers et al. 2000). Using semiquantitative fluorescence immunocytochemical analysis, the authors also showed an approximately sevenfold increase of Pdx- 1 expression in exocrine tissue, but not within the islet in control nondiabetic mice treated with exendin- 4 for 2 weeks. None of these authors reported the presence of transcription factors other than Pdx-1. Despite these reports on the association between $\mathrm{Pdx}-1$ and islet neogenesis in postnatal life, our results represent the first quantitative determination of mass increase of these cells, and of their compartmentalization in the pancreas, concomitant with a process of postnatal islet neogenesis induced by dietary manipulation during fetal development.

Our report provides additional novel data regarding Pdx-1-positive cells and islet neogenesis: (1) a different increment of these cells at the three pancreas compartments (with the main increase occurring in ductal cells), and (2) the existence of two cell subpopulations, Pdx-1/ INGAP-positive and Pdx-1/INGAP-negative, the former being those that underwent the highest increase (cell mass and number) in $\mathrm{S}$ animals, indicating their greater capacity to react in response to an increased insulin demand.

While some cells showing positivity for either $\mathrm{Pdx}-1$ or INGAP also stained with insulin and glucagon respectively (Del Zotto et al. 2000), Pdx-1/INGAP-positive cells were neither stained with insulin, glucagon, somatostatin, and PP antibodies, nor with the Ngn-3 antibody. Thus, based on these two conditions (absence of hormone 


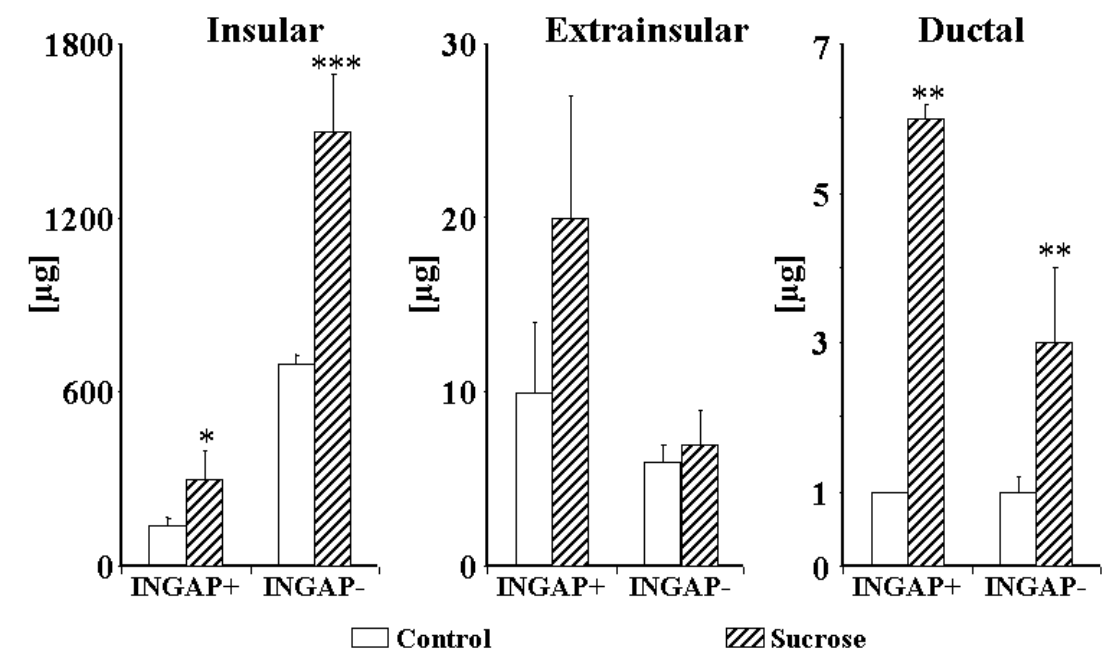

Figure 5 Changes induced by sucrose-feeding in Pdx-1-positive cells. Each value represents the mean of Pdx-1-cell mass \pm S.E.M. of three animals from each group and from two different levels of each paraffin block. ${ }^{* *} P<0 \cdot 005$; ${ }^{* *} P<0 \cdot 02$; ${ }^{*} P<0 \cdot 03$.

Table 4 Number of Pdx-1/INGAP-positive and Pdx-1/INGAP-negative cells. Each value represents the mean number of cells/area (10 mm²) from three animals and three different section levels \pm S.E.M.

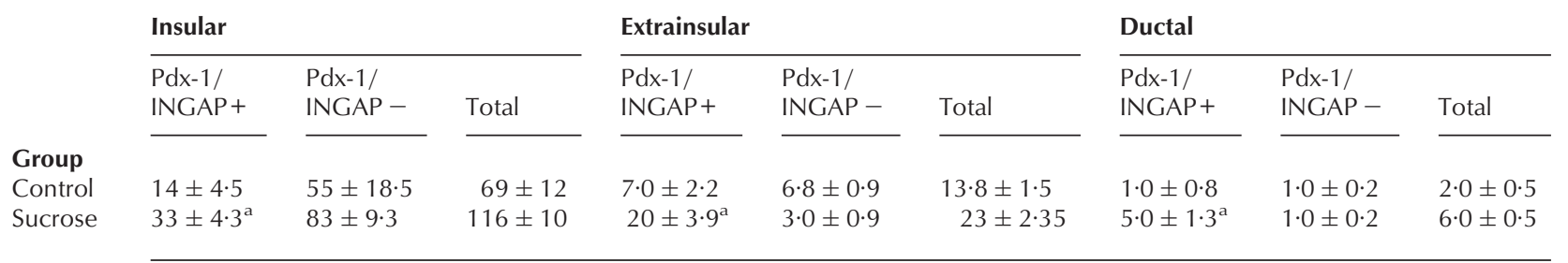

ap $<0 \cdot 02$.

Total number of cells counted in each C and S pancreas subsector: insular, 2743 and 2995; ductal, 1003 and 1974 ; extrainsular, 486 and 505 respectively.

immunoreactivity and high growth reactivity), we have assumed that these cells represent a subpopulation of islet cell precursors at an early stage of development.

According to Grapin-Botton et al. (2001), the absence of Ngn-3 in these precursor cells could represent an advantage since it offers the chance to differentiate towards any of the islet cells according to demand. However, it is unlikely that $\mathrm{Pdx}-1$ expression in all non-islet cells is sufficient per se to cause differentiation into endocrine cells (Habener \& Stoffers 1998). The presence of other differentiation factors (INGAP?), and/ or perhaps a specific topography within the pancreatic parenchyma (proximity with ductal structure and/or mature islets) may allow some $\mathrm{Pdx}-1$-positive cells to progress towards a fully differentiated $\beta$-cell phenotype (Perfetti et al. 2000). In any case, our results suggest that INGAP would be a marker of a subpopulation of $\mathrm{Pdx}-1$-positive cells that will undergo a more active differentiation in situations where neogenesis is stimulated.

We cannot explain at the moment the mechanism for any possible interaction between Pdx-1 and INGAP. Since complex phosphorylation and nuclear translocation are steps involved in Pdx-1 activation (Stoffers et al. 2000), they could be alternative pathways where INGAP exerts its hypothetical effect.

The morphological and functional changes induced in the pancreas of normal adult rats and hamsters by sucrose ingestion has been ascribed to an insulin resistance state (Lombardo et al. 1996, Del Zotto et al. 1999). However, the main mechanism triggering the low tissue response to insulin in S hamsters is not completely clear. In the current experiment, despite the fact that the offspring were not fed directly with sucrose, they developed even more marked functional and morphological changes in their endocrine pancreas as compared with $\mathrm{S}$ adult animals. It could thus be assumed that some unidentified 'metabolic signal' (fructose?) could be present in both maternal circulation and breast milk, triggering the abovementioned pancreatic changes.

In brief, our results have shown that the offspring from $S$ hamsters present an apparent increased insulin secretion, and a simultaneous increase in $\beta$-cell mass. The latter was accompanied by an increase in the replication rate of $\beta$-cells as well as of their precursor duct cells, and, in islet 
neogenesis, together with a decrease in $\beta$-cell apoptotic rate. These changes were associated with an increase in INGAP-positive cell mass in the islet and duct pancreas subsectors, and in the mass of Pdx-1-positive cells, particularly those which are INGAP-positive and located in the ducts. Altogether, these results reinforce the hypothesis that INGAP participates in the regulation of pancreas growth and secretory function, allowing the gland to cope with the peripheral insulin demand. Additionally, the appearance of INGAP immunoreactivity in Pdx-1-positive cells could become a useful marker for the identification of stem cells in the pancreas, which will follow a more active differentiation in the case of neogenesis.

\section{Acknowledgements}

This study was partially supported by funds from CONICET, FONCYT, and CICPBA of Argentina. The authors are grateful to $\mathrm{C}$ Bianchi and A Díaz for technical assistance, and A Di Maggio for careful secretarial support.

\section{References}

Bertelli E, Regoli M, Orazioli D \& Bendayan M 2001 Association between islets of Langerhans and pancreatic ductal system in adult rats. Where endocrine and exocrine meet together? Diabetologia 44 $575-584$.

Bonner-Weir S 2000 Islet growth and development in the adult. Journal of Molecular Endocrinology 24 297-302.

Bonner-Weir S \& Smith FE 1994 Islet cell growth and the growth factors involved. Trends in Endocrinology and Metabolism 5 60-64.

Bouwens L \& Kloppel G 1996 Islet cell neogenesis in the pancreas. Virchows Archives 427 553-560.

Bouwens L, Wang RN, De Blay E, Pipeleers DG \& Klöppel G 1994 Cytokeratins as markers of ductal cell differentiation and islet neogenesis in the neonatal rat pancreas. Diabetes 43 1279-1283.

Del Zotto H, Massa L, Gómez Dumm CL \& Gagliardino JJ 1999 Changes induced by sucrose administration upon the morphology and function of pancreatic islets in the normal hamster. Diabetes and Metabolism Research Review 15 106-112.

Del Zotto H, Massa L, Rafaeloff R, Pittenger GL, Vinik A, Gold G, Reifel-Miller A \& Gagliardino JJ 2000 Possible relationship between changes in islet neogenesis and islet neogenesis-associated protein-positive cell mass induced by sucrose administration to normal hamsters. Journal of Endocrinology 165 725-733.

Edlund H 1998 Transcribing pancreas. Diabetes 47 1817-1823.

Fernandes A, King LC, Guz Y, Stein R, Wright CV \& Teitelman G 1997 Differentiation of new insulin-producing cells is induced by injury in adult pancreatic islets. Endocrinology 138 1750-1762.

Flores LE, García ME, Borelli MI, Del Zotto H, Alzugaray ME, Maiztegui B \& Gagliardino JJ 2003 Expression of islet neogenesisassociated protein in islets of normal hamsters. Journal of Endocrinology 177 243-248 (see this issue).

Gagliardino JJ, Del Zotto H, Massa L, Reifel-Miller A, Gold G \& Vinik AI 2000 Simultaneous increase in B-cell and INGAP-positive cell mass in offspring of sucrose-fed pregnant normal hamsters. Diabetes 49 (Suppl 1): A415 (Abstract).

German M, Ashcroft S, Docherty K, Edlund H, Goodison S, Imura H, Kennedy G, Madsen O, Malloul D et al. 1995 The insulin gene promoter. A simplified nomenclature. Diabetes 44 1002-1004.
Gradwohl G, Dierich A, LeMeur M \& Guillemot F 2000

Neurogenin 3 is required for the development of the four endocrine cell lineages of the pancreas. PNAS 97 1607-1611.

Grapin-Botton A, Majithia AR \& Melton DA 2001 Key events of pancreas formation are trigged in gut endoderm by ectopic expression of pancreatic regulatory genes. Genes and Development $\mathbf{1 5}$ 444-454.

Habener JF \& Stoffers DA 1998 A newly discovered role of transcription factors involved in pancreas development and the pathogenesis of diabetes mellitus. Proceedings of the Association of American Physicians 110 12-21.

Herbert V, Lau KS, Gottlieb CW \& Bleicher SJ 1965 Coated charcoal immunoassay of insulin. Journal of Clinical Endocrinology and Metabolism 25 1375-1384.

Hsu SM, Raine L \& Fanger H 1981 Use of avidin-biotin-peroxidase complex $(\mathrm{ABC})$ in immunoperoxidase techniques: a comparison between $\mathrm{ABC}$ and unlabeled antibody (PAP) procedures. Journal of Histochemistry and Cytochemistry 29 577-580.

Jensen J, Heller RS, Funder-Nielsen T, Pedersen EE, Lindsell C, Weinmaster G, Madsen OD \& Serup P 2000 Independent development of pancreatic alpha- and beta-cells from neurogenin3-expressing precursors: a role for the notch pathway in repression of premature differentiation. Diabetes 49 163-176.

Karlsson O, Edlund T, Moss JB, Rutter WJ \& Walker MD 1987 A mutational analysis of the insulin gene transcription control region: expression in beta cells is dependent on two related sequences within the enhancer. PNAS $\mathbf{8 4} 8819-8823$.

Kaung HL 1994 Growth dynamics of pancreatic islet cell populations during fetal and neonatal development of the rat. Developmental Dynamics 200 163-175.

Linde S, Hansen B \& Lernmark A 1980 Stable iodinated polypeptide hormones prepared by polyacrylamide gel electrophoresis. Annals of Biochemistry 107 165-176.

Lombardo YB, Drago S, Chicco A, Fainstein-Day P, Gutman R, Gagliardino JJ \& Gomez Dumm CL 1996 Long-term administration of a sucrose-rich diet to normal rats: relationship between metabolic and hormonal profiles and morphological changes in the endocrine pancreas. Metabolism 45 1527-1532.

McKinnon CM \& Docherty K 2001 Pancreatic duodenal homeobox-1, PDX-1, a major regulator of beta cell identity and function. Diabetologia 44 1203-1214.

Madsen OD, Jensen J, Petersen HV, Pedersen EE, Oster A, Andersen FG, Jorgensen MC, Jensen PB, Larsson LI \& Serup P 1997 Transcription factors contributing to the pancreatic beta-cell phenotype. Hormone and Metabolic Research 29 265-270.

Massa L, Del Zotto H, Gómez Dumm CL \& Gagliardino JJ 1997 Postnatal sequential changes in islet morphology and insulin secretion of normal hamsters. Pancreas 14 58-64.

Montanya E, Nacher V, Biarnes M \& Soler J 2000 Linear correlation between beta-cell mass and body weight throughout the lifespan in Lewis rats: role of beta-cell hyperplasia and hypertrophy. Diabetes 49 1341-1346.

Perfetti R, Zhou J, Doyle ME \& Egan JM 2000 Glucagon-like peptide- 1 induces cell proliferation and pancreatic-duodenum homeobox-1 expression and increases endocrine cell mass in the pancreas of old, glucose-intolerant rats. Endocrinology 141 4600-4605.

Rosenberg L, Brown RA \& Duguid WP 1983 A new approach to the induction of duct epithelial hyperplasia and nesidioblastosis by cellophane wrapping of the hamster pancreas. Journal of Surgical Research 35 63-72.

Scaglia L, Cahill CJ, Finegood DT \& Bonner-Weir S 1997 Apoptosis participates in the remodeling of the endocrine pancreas in the neonatal rat. Endocrinology 138 1736-1741.

Shafrir RE, Ben-Sasson R, Ziv E \& Bar-On H 1999 Insulin resistance, $\beta$-cell survival, and apoptosis in type 2 diabetes: animal models and human implications. Diabetes Reviews 7 114-123. 
Sharma A, Zangen DH, Reitz P, Taneja M, Lissauer ME, Miller CP, Weir GC, Habener JF \& Bonner-Weir S 1999 The homeodomain protein IDX-1 increases after an early burst of proliferation during pancreatic regeneration. Diabetes 48 507-513.

Stoffers DA, Kieffer TJ, Hussain MA, Drucker DJ, Bonner-Weir S, Habener JF \& Egan JM 2000 Insulinotropic glucagon-like peptide 1 agonists stimulate expression of homeodomain protein IDX-1 and increase islet size in mouse pancreas. Diabetes 49 741-748.
Swenne I 1983 Effects of aging on the regenerative capacity of the pancreatic B-cell of the rat. Diabetes 32 14-19.

Wang RN, Kloppel G \& Bouwens L 1995 Duct- to islet-cell differentiation and islet growth in the pancreas of duct-ligated adult rats. Diabetologia 38 1405-1411.

Received 4 November 2002

Accepted 15 January 2003 